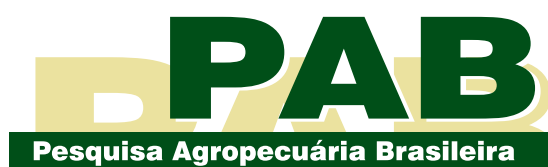

ISSN 1678-3921

Journal homepage: www.embrapa.br/pab

For manuscript submission and journal contents, access: www.scielo.br/pab

\section{Agronomic performance of both virus-infected and virus-free garlic with different seed bulbs and clove sizes}

\begin{abstract}
The objective of this work was to evaluate the growth and production of a garlic clone subjected to either infection or virus-free conditions, according to bulb and clove size classification. The experiment was carried out in a randomized complete block design with four replicates. Treatments consisted of either virus-infected or virus-free cloves, obtained from bulbs of four size classes and from cloves with three sieve diameters. Vegetative characteristics and plant production were assessed. Plants infected by viral complexes showed a reduction in emergence (8.4\%), plant height $(9.8 \%)$, and production of marketable bulbs (39.4\%), as well as a lower average mass of bulbs and cloves. The virus-free clone produced more bulbs in classes $5(42-47 \mathrm{~mm}), 6(47-56 \mathrm{~mm})$, and $7(>56 \mathrm{~mm})$, besides having a lower influence on marketable quality standards as a function of garlic seed size variation. In the infected clone, bulbs from sieve 6 and cloves from sieve 1 $(15 \times 25 \mathrm{~mm})$ produced bulbs with the highest market value. Virus-free garlic seed, with bulbs and cloves of medium and large size, produce bulbs of the highest market value, whereas, for the infected garlic, this is possible only with the larger garlic size.
\end{abstract}

Index terms: Allium sativum, garlic seed, marketable size, vegetative growth.

\section{Desempenho agronômico de alho infectado e de alho livre de vírus com diferentes tamanhos de bulbos e bulbilhos}

Resumo - O objetivo deste trabalho foi avaliar o crescimento e a produção de um clone de alho submetido a condições de infecção viral e livre de vírus, com base na classificação por tamanho de bulbos e bulbilhos. O delineamento experimental foi em blocos ao acaso, com quatro repetições. Os tratamentos consistiram de bulbilhos infectados com vírus ou não infectados, obtidos de bulbos de quatro classes de tamanho e de bulbilhos com três diâmetros de peneira. Avaliaram-se as características vegetativas e a produção das plantas. As plantas infectadas por complexos virais apresentaram redução na emergência $(8,4 \%)$, na altura de planta $(9,8 \%)$ e na produção comercial de bulbos (39,4\%), além de menor massa média de bulbos e bulbilhos. O clone livre de vírus teve maior produção de bulbos nas classes $5(42-47 \mathrm{~mm}), 6$ (47-56 mm) e 7 ( $>56 \mathrm{~mm})$, bem como menor influência no padrão comercial, em razão da variação do tamanho do alho-semente. No clone infectado, os bulbos de classe 6 e os bulbilhos de peneira $1(15 \times 25)$ produziram bulbos de maior valor comercial. $\mathrm{O}$ alho-semente livre de vírus e com bulbos e bulbilhos de tamanho médio e grande produz bulbos de maior valor comercial, enquanto, para o alho infectado, isto só é possível com o alho de maior tamanho.

Termos para indexação: Allium sativum, alho-semente, classificação comercial, desenvolvimento vegetativo. 


\section{Introduction}

Virus multiplication and dissemination in garlic, from one production cycle to another, is facilitated by propagules (bulbs and cloves) due to the vegetative propagation. The presence of a viral complex in garlic, formed by the genera Allexivirus, Carlavirus, and Potyvirus (Mituti et al., 2011, 2015; Oliveira et al., 2014; Torrico et al., 2015) causes a drastic reduction of the vegetative vigor and productivity of the crop over time (Perotto et al., 2010; Oliveira et al., 2014; Velásquez-Valle et al., 2017), leading to the degeneracy of cultivars.

The production of virus-free plants, with the consequent recovery of vigor and productivity of garlic, has been possible through tissue culture techniques, with in vitro cultivation of stem tips associated with thermotherapy (Menezes Júnior, 2011; Oliveira et al., 2014; Vieira et al., 2015). Thus, the propagation of viruses from one generation to another can be avoided, or reduced, allowing of $80 \%$ of virus-free plants to be obtained (Menezes Júnior, 2011).

The virus-free garlic technique has been consolidating as an essential technology for increasing the competitiveness of garlic production chain in Brazil. Significant increases of productivity and quality of bulbs provided by the use of virus-free garlic seed have been observed in both comparative tests with infected materials and their adoption in marketable plantations (Silva et al., 2010; Melo et al., 2011; Bereda \& Paduch-Cichal, 2016).

Productivity reduction varies according to the levels of viral infection of the cultivar, genetic material, and years of conventional clove multiplication. In this sense, Silva et al. (2010) observed a higher productivity in cloves from tissue culture for nine consecutive years, in comparison to the conventional multiplication. Depending on the cultivar used, the production tends to reduce from the third or fourth year of successive cultivation. Resende et al. (1995) observed that virusfree clones were up to $100 \%$ more productive than the original infected material. In addition, Bereda \& Paduch-Cichal (2016) found an increase of productivity by 14 to $32 \%$ when using virus-free clones.

In the conventional crop multiplication system, in which predominates the use of virus-contaminated garlic seed, the combined selection of the largest sizes of bulbs and cloves for the setting of a marketable cultivation has been adopted as a rule, mainly by more technical producers. This fact is confirmed by Oliveira et al. (2014) who reported that the largest and most vigorous bulbs have a lower percentage of virus infection.

Studies carried out with virus-infected garlic indicate that the highest amount of nutritional reserves in cloves results in plants with higher vigor, vegetative growth, and leaf area, leading to a production of bulbs of higher mass and diameter. Therefore, the use of bulbs and cloves of larger size as garlic seed has a direct relationship with an increase in productivity and classification of bulbs in classes of higher market value (Castellanos et al., 2004).

From the introduction of virus-free garlic in marketable plantations, cultivar degeneracy may become less important as a conditioning factor for the selection of larger bulbs/cloves as garlic seed. Thus, the influence of garlic seed size on the growth and productivity of these materials needs to be better understood. Virus-free bulbs/cloves with a lowerreserve content used in planting may provide the same potential for vegetative vigor and production, as those of larger sized seed of infected garlic. This possibility has aroused interest and expectation of garlic producers because of the great possible impacts on the reduction of the costs of crop setting.

Another aspect with few reports in Brazil refers to the possible interactions of size or weight of bulbs and cloves that compose the garlic seed. Thus, there are uncertainties on whether cloves with a higher content of reserves have the same vigor and production capacity irrespectively of its bulb size of origin.

The objective of this work was to evaluate the growth and production of a garlic clone subjected to either infection or virus-free conditions, according to bulb and clove size classification.

\section{Materials and Methods}

The experiment was carried out at a property specialized in garlic production, in the city of Planaltina (15'27'10"S; 47³6'5"W, at 944 m altitude), DF, Brazil. According to the Köppen-Geiger's classification, the regional climate is Aw, a tropical climate with a dry season in the winter and pluvial precipitations concentrated in the summer. During the experimental period, the average temperature was $20.5^{\circ} \mathrm{C}$ and the relative air humidity was $62 \%$. The soil is classified 
as a Latossolo Vermelho distroférrico A moderado, according to the Brazilian soil classification system (Santos et al., 2013), i.e., a clayey Oxisol.

The tests were performed using virus-free or virusinfected clones (cloves) from the high-quality 'Chonan' garlic. The experimental design was a randomized complete block with four replicates. The trial was carried out in two areas, one for each material (virusfree and infected) located side by side, and under the same cultivation conditions. The treatments were arranged in a factorial scheme consisting of four bulb size classes, according to the transversal diameter, and three clove sizes. The bulb size classes were defined according to Brasil (1992) as class 6 (greater than 47 to $56 \mathrm{~mm}$ ), class 5 (greater than 42 to $47 \mathrm{~mm}$ ), class 4 (greater than 37 to $42 \mathrm{~mm}$ ), and class 3 (greater than 32 to $37 \mathrm{~mm}$ ); and the three clove sizes were classified as sieve $1(15 \times 25 \mathrm{~mm})$, sieve $2(10 \times 20 \mathrm{~mm})$, and sieve $3(8 \times 17 \mathrm{~mm})$.

Both the virus-free clone and the infected cultivar were obtained from Embrapa Hortaliças. The virusfree clone was provided by the laboratory of cell biology and had undergone thermotherapy, followed by in vitro culture of stem tips; and the originally infected cultivar was obtained from the active germplasm bank. The viral cleansing of the virus-free clone was verified and guaranteed by the dot-Elisa serological test (Hammond \& Jordan, 1990) for the viral complex of the genera Allexivirus, Carlavirus, and Potyvirus.

After the classification and separation of the bulbs and cloves into different size classes and sieves, the cloves were counted and weighed to obtain the average mass and estimation of reserve content (Table 1). Garlic seed were vernalized in a cold chamber for 50 days before planting, at $3-5^{\circ} \mathrm{C}$ and relative humidity between 65 and $70 \%$. Planting was carried out in 2.3 $\mathrm{m}$ beds, with four double rows with $0.12 \mathrm{~m}$ single interrow spacing, $0.42 \mathrm{~m}$ double interrow spacing, and $0.09 \mathrm{~m}$ between plants in the row (corresponding to 411,522 plants ha-1, and an area of $243 \mathrm{~cm}^{2}$ per plant).

Plots were composed of four double rows, with 4.67 $\mathrm{m}^{2}$ area. The useful area of $1.94 \mathrm{~m}^{2}$ was formed by two central double rows, with two plants being discarded at the end of each row, totaling 80 plants. Cultural and phytosanitary practices, as well as irrigation and fertilization management, were carried out according to the technical standards recommended and adopted by the producers of high-quality garlic in the Cerrado region of the Distrito Federal District and Goiás states.

The soil chemical analysis showed the following characteristics: $\mathrm{pH}$ in water, 6.0; organic matter, 2.61 dag $\mathrm{kg}^{-1} ; \mathrm{P}$ and $\mathrm{K}, 85.69$ and $268 \mathrm{mg} \mathrm{dm}^{-3}$, respectively; $\mathrm{Ca}, \mathrm{Mg}, \mathrm{H}+\mathrm{Al}$, and $\mathrm{CEC}, 5.4,1.4,2.59$, and 10.08 $\mathrm{cmol}_{\mathrm{c}} \mathrm{dm}^{-3}$, respectively; and $\mathrm{B}, \mathrm{Cu}, \mathrm{Fe}, \mathrm{Mn}, \mathrm{Zn}$, and $\mathrm{S}, 0.19,4.06,20.42,32.29,15.37$, and $16.08 \mathrm{mg} \mathrm{dm}^{-3}$ respectively. The planting fertilization was based on the soil analysis, and consisted and of $85 \mathrm{~kg} \mathrm{ha}^{-1}$ $\mathrm{N}$ and $595 \mathrm{~kg} \mathrm{ha}^{-1} \mathrm{P}_{2} \mathrm{O}_{5}$ applied as ammonium sulfate and triple superphosphate, respectively. The total topdressing fertilization consisted of $124 \mathrm{~kg} \mathrm{ha}^{-1}$ of $\mathrm{N}$ applied in two seasons. Moreover, $200 \mathrm{~kg} \mathrm{ha}^{-1}$ of ammonium sulfate and $200 \mathrm{~kg} \mathrm{ha}^{-1}$ of calcium nitrate were applied in the pre-differentiation stage at 25 days after planting (DAP). Topdressing fertilization was applied after water stress (65 DAP), and consisted of $150 \mathrm{~kg} \mathrm{ha}^{-1}$ ammonium sulfate and $150 \mathrm{~kg} \mathrm{ha}^{-1}$ Chilean saltpeter. No exclusive source of potassium was applied due to its high content in the soil.

The irrigation system was composed of a conventional sprinkler with a central pivot, and irrigation shifts were adopted according to the need and stage of the crop development. Total water depth of $400 \mathrm{~mm}$ was applied throughout the cycle. The irrigation shift was defined based on garlic crop evapotranspiration, taking into account temperature and relative air humidity. In the initial stage, a two-day irrigation shift was used with $8 \mathrm{~mm}$ per day volume and, in the vegetative growth, a $16 \mathrm{~mm}$ per day volume was applied every 4 day.

Table 1. Average mass of cloves (sieves) for virus-free (VFC) and virus-infected (VIC) garlic (Allium sativum) clones of the cultivar Chonan, as a function of the classification of bulbs by the transversal diameter, and of cloves, in sieves.

\begin{tabular}{|c|c|c|c|c|c|c|}
\hline \multirow{3}{*}{$\begin{array}{l}\text { Bulb } \\
\text { diameter }{ }^{(1)}\end{array}$} & \multicolumn{6}{|c|}{ Average mass of cloves (g per clove) } \\
\hline & \multicolumn{2}{|c|}{1} & \multicolumn{2}{|c|}{2} & \multicolumn{2}{|c|}{3} \\
\hline & VFC & VIC & VFC & VIC & VFC & VIC \\
\hline 6 & 4.75 & 4.88 & 3.54 & 3.53 & 2.26 & 2.30 \\
\hline 5 & 4.48 & 3.78 & 3.25 & 2.67 & 2.06 & 1.80 \\
\hline 4 & 3.72 & 3.54 & 2.89 & 2.04 & 2.13 & 1.67 \\
\hline 3 & 3.37 & 2.39 & 2.55 & 2.32 & 1.83 & 1.57 \\
\hline
\end{tabular}

(1) Size of bulbs from classes 6 ( $>47$ up to $56 \mathrm{~mm}$ ), 5 (>42 up to $47 \mathrm{~mm}$ ), 4 ( $>37$ up to $42 \mathrm{~mm}$ ), and $3(>32$ up to $37 \mathrm{~mm}$ ), and cloves from sieves 1 or large $(15 \times 25 \mathrm{~mm}), 2$ or medium $(10 \times 20 \mathrm{~mm})$, and 3 or small $(8 \times 17$ $\mathrm{mm})$. 
The irrigation was suspended at 55 DAP for 10 days, to promote water stress that is necessary to avoid the physiological abnormality known as secondary bulb growth (Macêdo et al., 2006).

During bulb growth, a $20 \mathrm{~mm}$ per day volume was used with a 4-day irrigation shift. In the maturation period, the volume used was $5 \mathrm{~mm}$ per day, with 4-day irrigation shifts. In the final stage of maturation, irrigation was interrupted 10 days before harvest.

Before planting, seed cloves were treated with procymidone and carbendazim, in order to protect them against soil pathogens, and abamectin for controlling storage mites. The fungicides pyraclostrobin, propineb, trifloxystrobin, tebuconazole, and captan were used to control Alternaria porri, Puccinia allii; and betacyfluthrin and triflumuron were used for controlling Trips tabaci. The herbicides ioxynil octanoate and clethodim were applied in plant post-emergence to control invasive plants.

Garlic seed emergence potential was assessed 15 days after planting (DAP) by means of counting all emerged plants from the useful area, with values expressed as percentage (\%). At 70 DAP, plant height, number of live leaves and bulb ratio were assessed in 10 random plants per plot. Plant height was measured with a millimeter ruler from the ground level to the end of the longest leaf, with values expressed in centimeter. The bulb ratio, which expresses the degree of development of the bulb at a given time in the crop cycle, was obtained by the ratio between the pseudostem diameter (at the height of plant neck) and bulb diameter measured with a digital caliper. Bulb ratio with values lower than 0.5 indicate a complete bulb formation, and values lower than 0.2 indicate a complete bulb maturation.

Leaf area (LA) and total fresh mass (TFM) were assessed at 90 DAP in a sample of three plants per plot. Leaf area was estimated $\left(\mathrm{cm}^{2}\right.$ per plant) in a leaf area integrator. The total fresh mass (g per plant) was measured by an analytical balance (two decimal places), including the total fresh mass of leaves, pseudostem, and bulb.

Harvesting was performed after bulb maturity at 125 DAP with $30 \%$ of leaves still green, and all plants of the useful area were used. The curing process was carried out in a shed for 20 days after harvest. After the curing process, the bulbs were separated from roots and leaves, by using a pruning shear, and then they were cleaned. The bulbs were separated into marketable sizes considering the transversal diameter, according to the Portaria $\mathrm{n}^{\circ} 242$ of September 17, 1992 enacted by the Ministry of Agriculture, Livestock and Food Supply (Brasil, 1992): nonmarketable bulbs (smaller than $32 \mathrm{~mm}$ ), class 3 (greater than 32 up to $37 \mathrm{~mm}$ ), class 4 (greater than 37 up to $42 \mathrm{~mm}$ ), class 5 (greater than 42 up to $47 \mathrm{~mm}$ ), class 6 (greater than 47 up to $56 \mathrm{~mm}$ ), and class 7 (greater than $56 \mathrm{~mm}$ ).

The relative production was calculated in the grouped classes $7+6$, class 5 , and the nonmarketable bulbs were calculated by the ratio between the bulb mass of each category and the total production. The values were expressed as percentage (\%).

The productivity of marketable bulbs (PMB) was determined by the sum of the mass $\left(\mathrm{Mg} \mathrm{ha}^{-1}\right)$ of the bulbs from classes 7, 6, 5, 4, and 3. The average mass of bulbs (MB) was determined by the ratio between the total mass of bulbs (g per bulb) and the total number of bulbs. The average mass of cloves (MC, g per clove) was determined by the ratio between the mass and the number of cloves in a sample of 20 cloves.

The data were subjected to a joint analysis of variance, to compare the tests performed with virusfree and virus-infected clones by means of the F test, at $5 \%$ probability. The means of treatments of the factors bulb and clove size were compared using the Tukey's test, at $5 \%$ probability.

\section{Results and Discussion}

Bulb and clove sizes independently influenced the growth and production of virus-free and virus-infected garlic, with no interaction between these factors for the assessed characteristics.

The joint analysis showed that the emergence in virus-infected clones was $8.4 \%$ lower than that of the virus-free clone. The presence of the viral complex in bulbs of classes 5 to 3 and cloves of sieve 3 , that is, of a smaller size, reduced the plant emergence (Table 2). However, in the virus-free clone, the size variation of bulbs and cloves did not influence the emergence, with the same emergence in all treatments.

The presence of virus in garlic plants does not directly lead to plant death. However, as these plants degenerate, they are more susceptible to other pathogens and to adverse environmental conditions, 
which reduces their survival capacity due to damages during emergence and stand (Lunello et al., 2007).

Plant height in virus-infected clones was $9.8 \%$ lower than that observed in the virus-free material. The use of bulbs and cloves of size 6 and 1, respectively, resulted in higher height of infected plants, while for virus-free plants the garlic seed size did not influence this characteristic (Table 2). Viral infections in garlic cause the gradual degeneracy of the crop, resulting in a reduced vegetative vigor (Conci et al., 2010), which is due to the higher height of virus-free plants (Resende et al., 1999, 2000) in comparison to infected plants. However, in the present work, the vigor reduction did not result in a change in the number of leaves, since both virus-free and virus-infected clones showed similar values of leaves due to a higher genetic control of this characteristic that is little influenced by the environment. In contrast, the size decrease of seed bulbs caused a significant reduction of the number of leaves in infected and virus-free plants.

In virus-infected clones, the lower-bulb ratio points to a more advanced bulbification, at $70 \mathrm{DAP}$, in bulbs of class 3 and cloves of sieve 3 (Table 3 ). In the virus-free clone, however, the different bulb and clove sizes did not change the bulb ratio. The early bulbification and premature senescence of plants are consequences of viral infection in garlic (Fayad-André et al., 2011). As

Table 2. Seedling emergence, plant height, and number of live leaves, as a function of sizes of bulbs and seed cloves from virus-free (VFC) and virus-infected (VIC) garlic (Allium sativum) clones of the cultivar Chonan ${ }^{(1)}$.

\begin{tabular}{|c|c|c|c|c|c|c|c|}
\hline \multirow[t]{2}{*}{ Size } & & \multicolumn{2}{|c|}{ Emergence (\%) } & \multicolumn{2}{|c|}{ Plant height $(\mathrm{cm})$} & \multicolumn{2}{|c|}{ Number of leaves } \\
\hline & & VFC & VIC & VFC & VIC & VFC & VIC \\
\hline \multirow{4}{*}{ Bulb } & 6 & $97.80 \mathrm{a}$ & $96.20 \mathrm{a}$ & $70.20 \mathrm{a}$ & $65.10 \mathrm{a}$ & $6.97 \mathrm{a}$ & $7.33 \mathrm{a}$ \\
\hline & 5 & $98.50 \mathrm{a}$ & $90.70 \mathrm{~b}$ & $68.20 \mathrm{a}$ & $61.20 \mathrm{~b}$ & $7.08 \mathrm{a}$ & $6.98 \mathrm{~b}$ \\
\hline & 4 & $98.30 \mathrm{a}$ & $87.10 \mathrm{bc}$ & $66.70 \mathrm{a}$ & $59.60 \mathrm{bc}$ & $6.81 \mathrm{ab}$ & $6.87 \mathrm{~b}$ \\
\hline & 3 & $98.30 \mathrm{a}$ & $86.10 \mathrm{c}$ & $64.50 \mathrm{a}$ & $57.40 \mathrm{c}$ & $6.52 \mathrm{~b}$ & $6.75 b$ \\
\hline \multirow{3}{*}{ Clove } & 1 & $98.10 \mathrm{a}$ & $92.60 \mathrm{a}$ & $72.80 \mathrm{a}$ & $63.80 \mathrm{a}$ & 7.18 & $7.36 \mathrm{a}$ \\
\hline & 2 & $98.50 \mathrm{a}$ & $90.90 \mathrm{a}$ & $68.10 \mathrm{a}$ & $60.50 \mathrm{~b}$ & $6.90 \mathrm{a}$ & $6.88 \mathrm{~b}$ \\
\hline & 3 & $98.10 \mathrm{a}$ & $86.50 \mathrm{~b}$ & $61.30 \mathrm{~b}$ & $58.10 \mathrm{c}$ & $6.45 \mathrm{~b}$ & $6.71 \mathrm{~b}$ \\
\hline Mean & & $98.20 \mathrm{~A}$ & $90.00 \mathrm{~B}$ & $67.40 \mathrm{~A}$ & $60.80 \mathrm{~B}$ & $6.84 \mathrm{~A}$ & $6.98 \mathrm{~A}$ \\
\hline $\mathrm{CV}(\%)$ & & \multicolumn{2}{|c|}{3.37} & \multicolumn{2}{|c|}{7.70} & \multicolumn{2}{|c|}{4.5} \\
\hline
\end{tabular}

${ }^{(1)}$ Means followed by equal lowercase letters in the columns, with values of bulbs and clove sizes, do not differ by Tukey's test, at 5\% probability. Uppercase letters in the rows compare VFC with VIC for each variable, by the $\mathrm{F}$ test, at $5 \%$ probability. observed in the present study, these facts aggravated in bulbs/cloves of smaller size, reducing the vegetative cycle of plants. These observations are in accordance with Resende et al. (1999), who observed a higher bulb ratio in virus-free garlic during the bulb maturation phase.

In virus-infected clones, bulbs of class 6 and cloves of sieve 1 resulted in plants with a higher leaf area and more fresh mass. This increase of the vegetative growth occurs due to a higher amount of nutritional reserve in the initial phase of growth (Mahadeen, 2011), which allows of a higher initial plant growth, such as leaf length and width. However, with clonal cleaning, no differences were observed in these characteristics between the four classes of bulbs and in cloves of sieves 1 and 2, indicating that the absence of degeneracy in the garlic seed eliminated the effect between these treatments (Table 3).

For virus-infected clones, bulbs and cloves of larger sizes (class 6 and sieve 1) led to higher values of bulb production in classes 7,6 , and 5 . The reduction of size of bulbs and mainly cloves led to a significant increase in the percentage of bulbs classified as nonmarketable ones (Table 4). Similar results were reported by Jiménez-Vázquez et al. (2014), in which seed from bulbs of 52-59 $\mathrm{mm}$ increased the production by $278.4 \%$ in relation to bulbs of $36-43 \mathrm{~mm}$. The same

Table 3. Bulb ratio at 70 days after planting, leaf area (LA), and total fresh mass (TFM) of plants, at 90 days after planting, as a function of sizes of bulbs and seed cloves from virus-free (VFC) and virus-infected (VIC) garlic (Allium sativum) clones of the cultivar Chonan ${ }^{(1)}$.

\begin{tabular}{|c|c|c|c|c|c|c|c|}
\hline \multirow[t]{2}{*}{ Size } & & \multicolumn{2}{|c|}{ Bulb ratio } & \multicolumn{2}{|c|}{ LA ( $\mathrm{cm}^{2}$ per plant $)$} & \multicolumn{2}{|c|}{ TFM (g per plant) } \\
\hline & & VFC & VIC & VFC & VIC & VFC & VIC \\
\hline \multirow{4}{*}{ Bulb } & 6 & $0.36 \mathrm{a}$ & $0.39 \mathrm{a}$ & $238 \mathrm{a}$ & $267 \mathrm{a}$ & $51.59 \mathrm{a}$ & $55.05 \mathrm{a}$ \\
\hline & 5 & $0.35 \mathrm{a}$ & $0.37 \mathrm{ab}$ & $251 \mathrm{a}$ & $190 \mathrm{~b}$ & $52.50 \mathrm{a}$ & $42.92 b$ \\
\hline & 4 & $0.36 \mathrm{a}$ & $0.37 \mathrm{ab}$ & $202 a$ & $182 b$ & $42.47 \mathrm{a}$ & $39.07 \mathrm{~b}$ \\
\hline & 3 & $0.35 \mathrm{a}$ & $0.35 \mathrm{~b}$ & $198 \mathrm{a}$ & $165 b$ & $41.96 \mathrm{a}$ & $36.11 \mathrm{~b}$ \\
\hline \multirow{3}{*}{ Clove } & 1 & $0.38 \mathrm{a}$ & $0.39 \mathrm{a}$ & $250 \mathrm{a}$ & $252 a$ & $53.61 \mathrm{a}$ & $53.50 \mathrm{a}$ \\
\hline & 2 & $0.35 \mathrm{ab}$ & $0.37 \mathrm{ab}$ & $237 \mathrm{a}$ & $175 b$ & $50.13 \mathrm{a}$ & $39.69 b$ \\
\hline & 3 & $0.33 b$ & $0.36 \mathrm{~b}$ & $180 \mathrm{~b}$ & $177 \mathrm{~b}$ & $37.66 \mathrm{~b}$ & $36.67 b$ \\
\hline Mean & & $0.36 \mathrm{~A}$ & $0.36 \mathrm{~A}$ & $222 \mathrm{~A}$ & $201 \mathrm{~A}$ & $47.13 \mathrm{~A}$ & $43.28 \mathrm{~A}$ \\
\hline CV (\%) & & \multicolumn{2}{|c|}{7.89} & \multicolumn{2}{|c|}{26.20} & \multicolumn{2}{|c|}{23.50} \\
\hline
\end{tabular}

(1)Means followed by equal lowercase letters in the columns, with values of bulb and clove sizes, do not differ by Tukey's test, at 5\% probability. Uppercase letters in the rows compare VFC with VIC for each variable, by the $\mathrm{F}$ test, at $5 \%$ probability. 
fact was observed for large cloves (4.0 to $7.2 \mathrm{~g}$ per clove) in relation to those considered small (2.0 to 4.3 g per clove), which resulted in a $309.6 \%$ increase of production. Mahadeen (2011) observed a 75\% higher bulb production using cloves of larger size (3.1 to 4 $\mathrm{g}$ per clove), in comparison to small cloves $(<1 \mathrm{~g}$ per clove). These results are associated with the high amount of nutritional reserve of carbohydrates and minerals present in large cloves, which results in more vigorous plants with a faster establishment and better development than plants originating from small cloves.

In addition to productivity, the highest percentage of bulbs in classes 7, 6, and 5 results in higher profitability for the garlic producer because bulbs from these classes show higher market prices. As to percentage, the virus-free clone produces more bulbs in classes $7+6$ and 5, amounting to 92.6 and $25.3 \%$, respectively, in comparison to virus-infected clones. For the virus-free clone, cloves of sieves 1 and 2 resulted in a higher proportion of bulbs classified as sizes 7 and 6, while garlic seed from bulbs of classes 6 , 5 , and 4 provided higher garlic productivity of class 5 .

The productivity of marketable bulbs, average mass of bulbs and cloves, in the virus-infected clones were $39.5,11.3$, and $14.0 \%$ respectively, which is lower than those observed in the virus-free clone. A higher initial

Table 4. Bulb production of the marketable classes $6+7$, class 5 , and nonmarketable class ${ }^{(1)}$, as a function of sizes of bulbs and seed cloves from virus-free (VFC) and virus-infected (VIC) garlic (Allium sativum) clones of the cultivar Chonan ${ }^{(2)}$.

\begin{tabular}{|c|c|c|c|c|c|c|c|}
\hline \multirow[t]{2}{*}{ Size } & & \multicolumn{2}{|c|}{ Class 6+7 (\%) } & \multicolumn{2}{|c|}{ Class $5(\%)$} & \multicolumn{2}{|c|}{ Nonmarketable (\%) } \\
\hline & & VFC & VIC & VFC & VIC & VFC & VIC \\
\hline \multirow{4}{*}{ Bulb } & 6 & $20.54 a$ & $19.17 \mathrm{a}$ & $30.92 \mathrm{a}$ & $38.39 \mathrm{a}$ & $8.06 \mathrm{~b}$ & $6.58 \mathrm{~b}$ \\
\hline & 5 & $18.01 \mathrm{a}$ & $6.21 \mathrm{ab}$ & $32.78 \mathrm{a}$ & $18.60 \mathrm{~b}$ & $7.70 \mathrm{~b}$ & $15.75 \mathrm{a}$ \\
\hline & 4 & $14.68 \mathrm{a}$ & $6.11 \mathrm{ab}$ & $26.47 \mathrm{a}$ & $16.44 b$ & $13.20 \mathrm{ab}$ & $19.30 \mathrm{a}$ \\
\hline & 3 & $13.28 \mathrm{a}$ & $2.98 \mathrm{~b}$ & $22.68 \mathrm{a}$ & $16.39 \mathrm{~b}$ & $17.47 \mathrm{a}$ & $24.18 \mathrm{a}$ \\
\hline \multirow{3}{*}{ Clove } & 1 & $28.63 \mathrm{a}$ & $16.20 \mathrm{a}$ & $28.53 \mathrm{a}$ & $29.73 a$ & $7.11 \mathrm{~b}$ & $9.86 \mathrm{~b}$ \\
\hline & 2 & $16.31 \mathrm{~b}$ & $4.91 \mathrm{~b}$ & $29.93 \mathrm{a}$ & $21.30 \mathrm{~b}$ & $10.94 \mathrm{~b}$ & $18.27 \mathrm{a}$ \\
\hline & 3 & $4.94 \mathrm{c}$ & $4.74 b$ & $26.17 \mathrm{a}$ & $16.33 b$ & $16.77 \mathrm{a}$ & $21.24 \mathrm{a}$ \\
\hline Mean & & $16.63 \mathrm{~A}$ & $8.62 \mathrm{~B}$ & $28.21 \mathrm{~A}$ & $22.45 \mathrm{~B}$ & $11.61 \mathrm{~B}$ & $16.46 \mathrm{~A}$ \\
\hline CV $(\%)$ & & 59 & & 26. & 07 & & \\
\hline
\end{tabular}

${ }^{(1)}$ The data set was transformed to arcsine $\mathrm{x} / 100$ for the analysis of variance. ${ }^{(2)}$ Means followed by equal lowercase letters in the columns, with values of bulb and clove sizes, do not differ by Tukey's test, at $5 \%$ probability. Uppercase letters in the rows compare VFC with VIC for each variable, by the $\mathrm{F}$ test, at $5 \%$ probability. vegetative development led to plants with a higher photosynthetic leaf area, which results in a higher vegetative mass. The highest vegetative size results in larger cloves due to the translocation of nutrients and photoassimilates from leaves and pseudostem to bulbs, during the filling and maturation of plants (Mahadeen, 2011; Mathew et al., 2011; Gautam et al., 2014; Ahmed et al., 2015).

In virus-infected clones, the largest bulb of class 6 and the largest clove of sieve 1, used as seed, provided higher productivity of marketable bulbs, higher average bulb mass, and larger cloves. In the virus-free clone, on the other hand, no difference was observed in the productivity of marketable bulbs between sizes of garlic seed from bulbs of classes 6, 5, and 4 and cloves of sieves 1 and 2 (Table 5). Bulb and clove sizes used as seed influence the garlic productivity so that the larger the propagation material size, the higher the productivity (Jiménez-Vázquez et al., 2014).

The gain in productivity through the use of virusfree clones has been widely reported in researches (Silva et al., 2010; Melo et al., 2011; Bereda \& PaduchCichal, 2016) and marketable plantations. According to Resende et al. (2000), the virus-free clone shows a vegetative vigor superior to virus-infected ones, which leads to an increased productivity. In addition, the

Table 5. Productivity of marketable bulbs (PMB), average mass of bulbs (MB), and average mass of cloves (MC), as a function of sizes of bulbs and seed cloves from virus-free (VFC) and virus-infected (VIC) garlic (Allium sativum) clones of the cultivar Chonan ${ }^{(1)}$.

\begin{tabular}{|c|c|c|c|c|c|c|c|}
\hline \multirow[t]{2}{*}{ Size } & & \multicolumn{2}{|c|}{$\operatorname{PMB}\left(\mathrm{Mg} \mathrm{ha}^{-1}\right)$} & \multicolumn{2}{|c|}{ MB (g per bulb) } & \multicolumn{2}{|c|}{ MC (g per clove) } \\
\hline & & $\mathrm{VFC}$ & VIC & VFC & VIC & VFC & VIC \\
\hline \multirow{4}{*}{ Bulb } & 6 & $10.11 \mathrm{a}$ & $9.56 \mathrm{a}$ & $24.70 \mathrm{a}$ & $26.11 \mathrm{a}$ & $2.18^{\mathrm{ns}}$ & $2.05 \mathrm{a}$ \\
\hline & 5 & $9.54 \mathrm{ab}$ & $6.11 \mathrm{~b}$ & $24.34 \mathrm{a}$ & $19.08 \mathrm{~b}$ & $2.17^{\mathrm{ns}}$ & $1.88 \mathrm{ab}$ \\
\hline & 4 & $8.05 \mathrm{ab}$ & $5.12 \mathrm{~b}$ & $21.53 \mathrm{a}$ & $18.84 \mathrm{~b}$ & $2.09^{\text {ns }}$ & $1.84 \mathrm{bc}$ \\
\hline & 3 & $7.06 \mathrm{~b}$ & $4.13 b$ & $19.96 \mathrm{a}$ & $17.30 \mathrm{~b}$ & $2.04^{\mathrm{ns}}$ & $1.69 \mathrm{c}$ \\
\hline \multirow{3}{*}{ Clove } & 1 & $10.78 \mathrm{a}$ & $8.17 \mathrm{a}$ & $26.08 \mathrm{a}$ & $24.01 \mathrm{a}$ & $2.22 \mathrm{a}$ & $1.97 \mathrm{a}$ \\
\hline & 2 & $8.56 \mathrm{ab}$ & $5.53 b$ & $22.87 \mathrm{ab}$ & $19.26 \mathrm{~b}$ & $2.15 \mathrm{a}$ & $1.81 \mathrm{~b}$ \\
\hline & 3 & $6.72 b$ & $4.99 \mathrm{~b}$ & $18.94 \mathrm{~b}$ & $17.73 b$ & $2.00 \mathrm{~b}$ & $1.82 \mathrm{~b}$ \\
\hline Mean & & 8.69A & $6.23 \mathrm{~B}$ & $22.63 \mathrm{~A}$ & $20.33 \mathrm{~B}$ & $2.12 \mathrm{~A}$ & $1.86 \mathrm{~B}$ \\
\hline CV (\%) & & \multicolumn{2}{|c|}{30.50} & \multicolumn{2}{|c|}{18.50} & \multicolumn{2}{|c|}{7.10} \\
\hline
\end{tabular}

(1) Means followed by equal lowercase letters in the columns, with values of bulb and clove sizes, do not differ by Tukey's test, at $5 \%$ probability. Uppercase letters in the rows compare VFC with VIC for each variable, by the $\mathrm{F}$ test, at $5 \%$ probability. 
presence of viruses in plants inhibits the photosynthesis and affects the synthesis and transport of assimilates to the bulb, which leads to a reduction of the average mass.

The use of large bulbs and cloves in the plantation, despite providing a higher productivity, results in an increase of production costs due to a higher expenditure for seed (Castellanos et al., 2004). This result is observed in high-technology systems in Brazil that use larger seed. However, higher production costs may cause a greater vulnerability to the garlic producer in years of low-market prices. In the present study, the virus-free clone, bulbs of classes 6,5 , and 4 , and cloves of sieves 1 and 2 showed higher of and similar values to productivity of marketable bulbs. Probably, the use of medium-sized propagation material reduces the planting costs, ensuring a higher profitability in the garlic cultivation.

The results obtained in the present study indicate that for the vegetative development, as well as for production and qualitative characteristics, the absence of virus in garlic seed compensates up to a certain limit the smaller size of propagation structures. This aspect indicates that the selection of bulbs and cloves for planting should take into account differentiated criteria in relation to infected garlic.

\section{Conclusions}

1. The virus-free material provides the increase of emergence, plant height, average bulb mass, and marketable bulb production of garlic (Allium sativum), in comparison to the infected material.

2. In the virus-infected clone, the class- 6 bulbs and sieve- 1 cloves are more productive and show a higher percentage of bulbs in the classes with higher market value.

3. In virus-free garlic there are no differences between bulbs size $6,5,4$, and sieve 1 and 2 cloves for marketable productivity and bulbs classified in the highest-market value classes.

\section{Acknowledgments}

To Conselho Nacional de Desenvolvimento Científico e Tecnológico (CNPq) and to Coordenação de Aperfeiçoamento de Pessoal de Nível Superior (Capes), for financial support.

\section{References}

AHMED, H.G.; SAIDU, Y.I.; ALIYU, U.; MUHAMMAD, A.S. Effects of clove size and defoliation stages on yield parameters of garlic (Allium sativum L.) in Sokoto, Nigeria. African Journal of Agricultural Science and Technology, v.3, p.544-548, 2015.

BEREDA, M.; PADUCH-CICHAL, E. Allexiviruses - pathogens of garlic plants. Progress in Plant Protection, v.56, p.302-311, 2016. DOI: https://doi.org/10.14199/ppp-2016-049.

BRASIL. Ministério da Agricultura. Portaria n ${ }^{\circ} 242$, de 17 de setembro de 1992. [Aprova a Norma de Identidade, Qualidade, Acondicionamento, Embalagem e Apresentação do Alho]. 1992. Available at: <http://www.codapar.pr.gov.br/arquivos/File/ pdf/alho242_92.pdf|>. Accessed on: Nov. 62018.

CASTELLANOS, J.Z.; VARGAS-TAPIA, P.; OJODEAGUA, J.L.; HOYOS, G.; ALCANTAR-GONZALES, G.; MENDEZ, F.S.; ALVAREZ-SANCHEZ, E.; GARDEA, A.A. Garlic productivity and profitability as affected by seed clove size, Planting Density and Planting Method. HortScience, v.39, p.1272-1277, 2004. DOI: https://doi.org/10.21273/HORTSCI.39.6.1272.

CONCI, V.C.; CANAVELli, A.E.; BALZARINI, M.G. The distribution of garlic viruses in leaves and bulbs during the first year of infection. Journal of Phytopathology, v.158, p.186-193, 2010. DOI: https://doi.org/10.1111/j.1439-0434.2009.01601.x.

FAYAD-ANDRÉ, M. de S.; DUSI, A.N.; RESENDE, R.O. Spread of viruses in garlic fields cultivated under different agricultural production systems in Brazil. Tropical Plant Pathology, v.36, p.341-349, 2011. DOI: https://doi.org/10.1590/S198256762011000600001.

GAUTAM, N.; KUMAR, D.; KUMAR, R.; KUMAR, S.; SHARMA, S.; DOGRA, B. Growth and yield of garlic (Allium sativum L) as influenced by clove weight and plant growth regulators. International Journal of Farm Sciences, v.4 p.49-57, 2014.

HAMMOND, J.; JORDAN, R.L. Dot blots (viruses) and colony screening. In: HAMPTON, R.; BALL, E.; DE BOER, S. (Ed.). Serological methods for detection and identification of viral and bacterial plant pathogens: a laboratory manual. Saint Paul: APS, 1990. p.237-248.

JIMÉNEZ-VÁZQUEZ, P.; RANGEL-LUCIO, J.A.; MENDOZAELOS, M.; CERVANTES-ORTÍZ, F.; RIVERA-REYES, J.G. Efecto de tamaño del bulbo/bulbillo y densidad de plantación en la emergencia, rendimiento y calidad de ajo (Allium sativum L.). Phyton, v.83, p.83-91, 2014.

LUNELLO, P.; DI RIENZO, J.; CONCI, V.C. Yield loss in garlic caused by Leek yellow stripe virus argentinean isolate. Plant Disease, v.91, p.153-158, 2007. DOI: https://doi.org/10.1094/PDIS91-2-0153.

MACÊDO, F.S.; SOUZA R.J. de; PEREIRA, G.M. Controle de superbrotamento e produtividade do alho vernalizado sob estresse hídrico. Pesquisa Agropecuária Brasileira, v.41, p.629-635, 2006. DOI: https://doi.org/10.1590/S0100-204X2006000400012.

MAHADEEN, A.Y. Influence of clove weight on vegetative growth and yield of garlic (Allium sativum L.) grown under drip 
irrigation. Jordan Journal of Agricultural Sciences, v.7, p.4450, 2011.

MATHEW, D.; FORER, Y.; RABINOWITCH, H.D.; KAMENETSKY, R. Effect of long photoperiod on the reproductive and bulbing processes in garlic (Allium sativum L.) genotypes. Environmental and Experimental Botany, v.71, p.166-173, 2011. DOI: https://doi.org/10.1016/j.envexpbot.2010.11.008.

MELO, W.F. de; RESENDE, F.V.; GUIDUCCI FILHO, E.; DUSI, A.N. Da bancada ao agricultor: a transferência da tecnologia de alho livre de vírus aos agricultores familiares da Bahia. Cadernos de Ciência \& Tecnologia, v.28, p.81-114, 2011.

MENEZES JÚNIOR, F.O.G. de. Cultivo in vitro do alho visando a limpeza clonal. Revista de Ciências Agroveterinárias, v.10, p.158-167, 2011.

MITUTI, J.; MARUBAYASHI, J.M.; MOURA, M.F.; KRAUSESAKATE, R.; PAVAN, M.A. First report of Shallot latent virus in garlic in Brazil. Plant Disease, v.95, p.227.2, 2011. DOI: https://doi.org/10.1094/PDIS-08-10-0599.

MITUTI, T.; MOURA, M.F.; MARUBAYASHI, J.M.; OLIVEIRA, M.L.; IMAIZUMI, V.M.; SAKATE, R.K.; PAVAN, M.A. Survey of viruses belonging to different genera and species in noble garlic in Brazil. Scientia Agrícola, v.72, p.278-281, 2015. DOI: https://doi.org/10.1590/0103-9016-2014-0168.

OLIVEIRA, M.L. de; NARDINI, J.P.C.; MARCHI, B.R. de; MITUTI, T.; BAMPI, D.; PAVAN, M.A.; KRAUSE-SAKATE, R. Análise da presença de vírus em alho semente da segunda e quarta gerações, produzidos por termoterapia e cultura de tecido. Summa Phytopathologica, v.40, p.75-77, 2014. DOI: https://doi.org/10.1590/S0100-54052014000100011.

PEROTTO, M.C.; CAFRUNE, E.E.; CONCI, V.C. The effect of additional viral infections on garlic plants initially infected with Allexiviruses. European Journal of Plant Pathology, v.126, p.489-495, 2010. DOI: https://doi.org/10.1007/s10658-009-9555-7.

RESENDE, F.V.; FAQUIN, V.; SOUZA, R.J. Efeito da adubação nitrogenada no crescimento e na produção de alho proveniente de cultura de tecidos e de multiplicação convencional. Revista Brasileira de Ciência do Solo, v.24, p.49-57, 2000. DOI: https://doi.org/10.1590/S0100-06832000000100007.

RESENDE, F.V.; SOUZA, R.J. de; FAQUIN, V. RESENDE, J.T.V. Comparação do crescimento e produção entre alho proveniente de cultura de tecidos e de multiplicação convencional. Horticultura Brasileira, v.17, p.118-124, 1999. DOI: https://doi.org/10.1590/ S0102-05361999000200009.

RESENDE, F.V.; SOUZA, R.J.de; PASQUAL, M. Comportamento, em condições de campo, de clones de alho obtidos por cultura de meristema. Horticultura Brasileira, v.13, p.44-46, 1995.

SANTOS, H.G. dos; JACOMINE, P.K.T.; ANJOS, L.H.C. dos; OLIVEIRA, V.A. de; LUMBRERAS, J.F.; COELHO, M.R.; ALMEIDA, J.A. de; CUNHA, T.J.F.; OLIVEIRA, J.B. de. Sistema brasileiro de classificação de solos. 3.ed. rev. e ampl. Brasília: Embrapa, 2013. 353p.

SILVA, E.C. da; SOUZA, R.J. de; PASQUAL, M. Diferenças de produtividade entre cultivares de alho obtidas por cultura de tecidos e multiplicação convencional, em um período de nove anos consecutivos. Bioscience Journal, v.26, p. 692-697, 2010.

TORRICO, A.K.; CELLI, M.G.; CONCI, L.R.; CONCI, V.C. Incidence of Garlic common latent virus in Argentina, and phylogenetic and recombination analyses of isolates. Pesquisa Agropecuária Brasileira, v.50, p.363-373, 2015. DOI: https://doi.org/10.1590/S0100-204X2015000500003.

VELÁSQUEZ-VALLE， R.; REVELES-HERNÁNDEZ， M.; CHEW-MEDINAVEITIA, Y.I.; REVELES-TORRES, L.R. Efecto del tratamiento térmico sobre la presencia de virus en bulbos de ajo (Allium sativum L.). Revista de la Facultad de Ciencias Agrarias Uncuyo, v.49, p.157-165, 2017.

VIEIRA,R.L.;SILVA,A.L.da;ZAFFARI,G.R.;STEINMACHER, D.A.; FRAGA, H.P. de F.; GUERRA, M.P. Efficient elimination of virus complex from garlic (Allium sativum L.) by cryotherapy of shoot tips. Acta Physiologiae Plantarum, v.37, art.1733, 2015. DOI: https://doi.org/10.1007/s11738-014-1733-3. 